Revue d'histoire de l'Amérique française

REYUE D.HISTOIRE DE L'AMÉRIQUE FRANÇAISE

\title{
Réplique de Madame Joanne Burgess
}

\section{Joanne Burgess}

Volume 37, numéro 3, décembre 1983

URI : https://id.erudit.org/iderudit/304195ar

DOI : https://doi.org/10.7202/304195ar

Aller au sommaire du numéro

Éditeur(s)

Institut d'histoire de l'Amérique française

ISSN

0035-2357 (imprimé)

1492-1383 (numérique)

Découvrir la revue

Citer ce document

Burgess, J. (1983). Réplique de Madame Joanne Burgess. Revue d'histoire de l'Amérique française, 37(3), 474-474. https://doi.org/10.7202/304195ar d'utilisation que vous pouvez consulter en ligne.

https://apropos.erudit.org/fr/usagers/politique-dutilisation/ 
Réplique de Madame Joanne Burgess.

La réplique de Messieurs Lamonde et LeBlanc ne m'amène pas à modifier le jugement que j'ai porté sur leur ouvrage. Leur affirmation que leur parcours de l'historiographie internationale sur la culture ouvrière ne devait servir qu'à «enrichir» la présentation d'une problématique et non pas fixer un cadre théorique ne me convainc pas. L'objectif des auteurs implique une conceptualisation de la culture ouvrière et renvoie donc à des perspectives théoriques. Leur concept de culture ouvrière me semble toujours manquer de clarté: il recouvre des phénomènes distincts et différents qui ne gagnent pas en compréhension à être fondus dans un terme unique. Ils nous rendent toutefois un service utile en rassemblant des informations éparses sur le monde ouvrier à Montréal de 1880 à 1920.

Département d' histoire

Université du Québec à Montréal

JOANNE BURGESS 